\title{
The Effect of Differentiated Instruction on Developing English Reading Comprehension Skill of Sixth Graders
}

\author{
Prepared by \\ Dr. Refat Mahmoud Bahgat \\ Emeritus Professor of Curriculum and Instruction \\ Qena Faculty of Education, South Valley University \\ Refat_bahgat@yahoo.com \\ Dr. Gamal Mohammed Shehata \\ Emeritus Professor of Curriculum and TEFL Methodology \\ Faculty of Education, Minia University \\ shehatagamat@yahoo.com \\ Dr. Amer Bakeer Ali \\ Lecturer of Curriculum and TEFL Methodology \\ Qena Faculty of Education, South Valley University \\ mereikhi@gmail.com \\ Mr. Mahfouz Haress Salem \\ English Language Instructor \\ Qena Faculty of Education, South Valley University \\ mahfouzsalem@edu.svu.edu.eg
}




\section{The Effect of Differentiated Instruction on Developing English Reading Comprehension Skill of Sixth Graders}

\section{Prepared by}

\author{
Prof. Dr. Refat Mahmoud Bahgat \\ Emeritus Professor of Curriculum \\ and Instruction \\ Qena Faculty of Education, \\ South Valley University \\ Refat_bahgat@yahoo.com
}

\author{
Dr. Amer Bakeer Ali \\ Lecturer of Curriculum and TEFL \\ Methodology \\ Qena Faculty of Education, South \\ Valley University \\ mereikhi@gmail.com
}

\author{
Dr. Gamal Mohammed Shehata \\ Emeritus Professor of Curriculum \\ and TEFL Methodology \\ Faculty of Education \\ Minia University \\ shehatagamat@yahoo.com
}

\author{
Mr. Mahfouz Haress Salem \\ English Language Instructor \\ Qena Faculty of Education, South \\ Valley University \\ mahfouzsalem@edu.svu.edu.eg
}

\section{Abstract:}

The present study aimed to investigate the effect of using differentiated instruction on developing reading comprehension of sixth year primary school students. The sample of the study consisted of 64 students (males and females). The control group $(\mathrm{n}=32)$ received traditional reading instruction (non-differentiated), whereas the experimental group $(n=32)$ received treatment (Differentiated Reading Instruction). Data were collected through English Reading Comprehension Test. Data collected were statistically analyzed quantitatively. For data analysis, descriptive statistics, independent samples, and t-test were used. For measuring the effect size of using differentiated instruction (independent variable) on English reading comprehension (dependent variable) of the experimental group participants, Eta Squared was computed using " $\mathrm{t}$ " value for the differences between the means. The study findings revealed that differentiated instruction had a great effect on developing experimental group students` reading comprehension skill as compared with the nondifferentiated group. In light of these results, the study concluded that differentiated instruction approach can be used effectively for teaching reading of sixth year primary students. Finally, the study recommended that differentiated instruction should be implemented in EFL contexts.

Keywords: differentiated instruction, reading comprehension skill 


$$
\begin{aligned}
& \text { أثر التدريس المتمايز في تنمية مهارة الفهم القرائي الإنجليزية لاى التى } \\
& \text { طلاب الصف السادس الابتدائي مئي } \\
& \text { إعداد } \\
& \text { د/ عامر بكير علي } \\
& \text { مدرس المناهج وطرق التّريس } \\
& \text { كلية التربية بقنا - جامعة جنوب الوادي وطري التين } \\
& \text { mereikhi@gmail.com }
\end{aligned}
$$

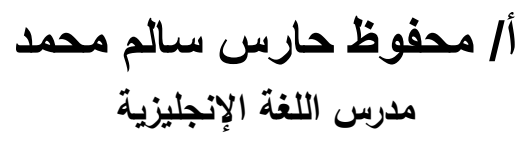

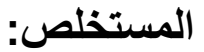

هدفت الدراسة إلي التعرف على أثز استخدام التدريس المتمايز في تتمية مهارة الفهم القرائي لدى الدى

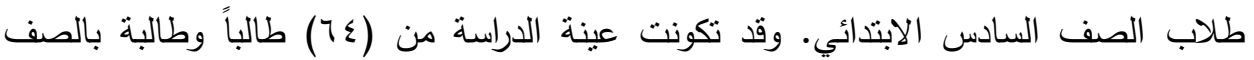

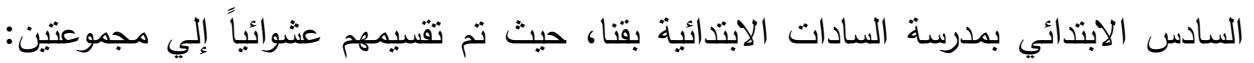

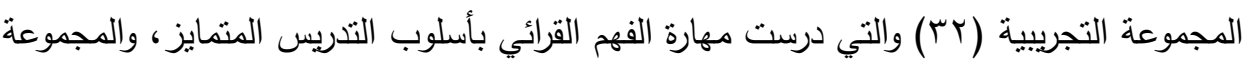
الضابطة (rr) والتي درست القراءة بالطريقة المعتادة. وقد تم جمع البيانات من خلال اختبار

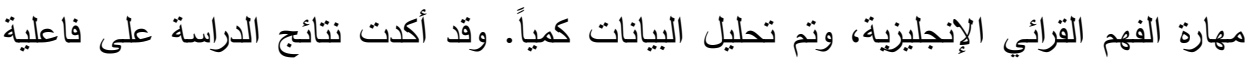

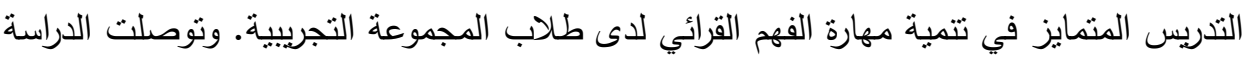

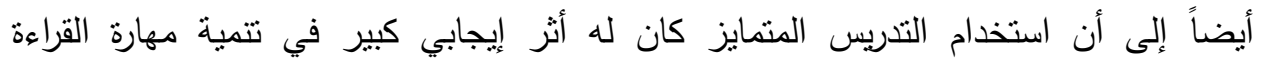
الإنجليزية. وفي ضوء نتائج الدراسة نم التوصل إلي أنه يمكن استخدام التدريس المتمايز بفعالية

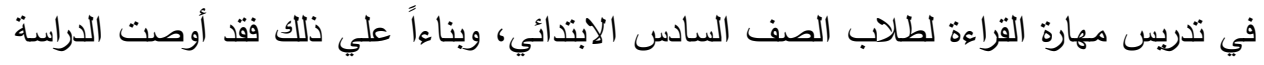

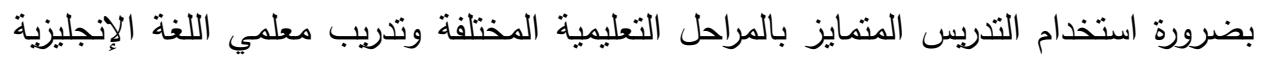

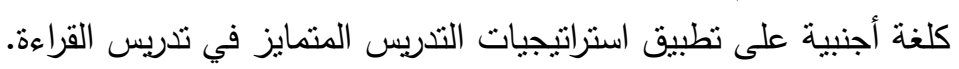
الكلمات المفتاحية: التدريس المتمايز ، مهارة الفهم القرائي. 


\section{The Effect of Differentiated Instruction on Developing English Reading Comprehension Skill of Sixth Graders}

Dr.Refat M. Bahagat Dr. Gamal M. Shehata Dr. Amer B. Ali Mr. Mahfouz H. Salem

\section{Background of the Study}

Reading skill plays a decisive role in shaping students' educational future and it is more important for academic achievement than any other skill (Gisler \& Eberts, 2009). Supporting this view, McGuire (2008) claimed that no skill is more important to student achievement than the ability to read and derive meaning from the printed page. Related to this, Kent (2005) mentioned that reading is a major skill that has a tremendous effect on student achievement at the elementary level. Paris (2005) stressed that learning to read is one of the greatest accomplishments in childhood because it is the foundation for learning and academic achievement.

Reading is not an easy task. According to Hamdan (2012), reading in a foreign language such as English might be a problem for some people. Snow, Burns, and Griffin (1998) mentioned that children who face early reading problem lack prior knowledge and relevant skills such as the ability to produce words, to distinguish sounds, to master the mechanics of reading and the ability to identify letters. In relation to this, D'Amico (2002) assured that $25 \%$ of students are unable to do the coursework because of their inability to read. Therefore, learners who have difficulty in reading at the elementary school may struggle reading until the end of their school life.

Besides, Durkin (1993) indicated that reading comprehension has come to be viewed as the "essence of reading", essential not only to academic learning but to life-long learning. In addition, Block and Pressley (2002) viewed that good readers who comprehend what they read are active. Those active readers think about what they read by using metacognitive strategies to correct problems with understanding.

Comprehension is the goal of reading; without it, students could not gain meaning from text (Adams, 1990; Block \& Pressley, 2002). Moreover, reading comprehension was defined by the National Reading Panel (NRP, 2000) as the ability to make connections between the known and the new information encountered in texts. It is also the ability to ask questions of the text, draw inferences during the reading, synthesize information across text, and visualize images while reading.

Reading comprehension skills allow us to read proficiently, learn effectively and to conceptualize. These skills are, basically, based on earlier stages of reading development, including oral reading and reading fluency. Without developing these earlier reading skills, students must continually focus on decoding letters and words, rather than progressing 


\section{The Effect of Differentiated Instruction on Developing English Reading Comprehension Skill of Sixth Graders}

Dr.Refat M. Bahagat Dr. Gamal M. Shehata Dr. Amer B. Ali Mr. Mahfouz H. Salem

to meaning and understanding (Grabe \& Stoller, 2002). Machado (2010) mentioned that reading begins with the decoding letters, letter groups and the sounding out of words. Machado also asserted that the movement from passive to active reading involves the development of reading comprehension skills.

In addition, researchers (i.e., Aaron, Joshi, \& Williams 1999; Catts, Adlof, \& Weismer, 2006; Elwer, 2014) maintained that a deficit in comprehension is the result of a specific problem in one of the two skills involved in reading comprehension (i.e., decoding or linguistic comprehension) or a combination of deficits in both. For this reason, Baier (2005) stated educators need to provide instruction to students in elementary and middle school to improve their reading and comprehension abilities before reaching high school (p. 3).

With respect to the teaching method in schools, sixth graders are taught as one homogeneous group. Their needs, interests and learning preferences are mostly ignored. Supporting this claim, Tomlinson (2001) stated that reading teachers are faced with the challenge of teaching a group of learners with diverse abilities. Tomlinson, Brimijoin and Narvaez (2008) stated that it is unrealistic to think that all students will thrive in classrooms that disregard their learning differences. Gregory and Chapman (2006) asserted that if the reading performance of students is to be improved, teachers must develop instruction in a way to meet the needs of individual learners. Thus, teachers' focus on the diverse learning needs of their students helps to improve achievement (Rock, Gregg, Ellis, $\&$ Gable, 2008).

In this respect, there are new trends and instructional approaches that take into account the students needs and give emphasis to their strengths rather than to their weaknesses. One of these approaches is differentiated instruction. Tomlinson (2005) defined differentiated instruction as a philosophy of teaching that is based on the premise that students learn best when their teachers accommodate the differences in their readiness levels, interests and learning profiles. Additionally, differentiated instruction is an instructional approach used to meet the academic and behavioral needs of a wide variety of diverse learners within the classroom setting (Edwards, Carr, \& Siegal, 2006).

Further, Tomlinson (2001) mentioned that instruction can be differentiated based on a student's readiness, learning profile or interest by varying three elements: First of all, Content: the materials or curriculum used. Second, Process: the activities or instructional strategies 


\section{The Effect of Differentiated Instruction on Developing English Reading Comprehension Skill of Sixth Graders}

Dr.Refat M. Bahagat Dr. Gamal M. Shehata Dr. Amer B. Ali Mr. Mahfouz H. Salem

implemented. Lastly, Product: the manner in which students demonstrate learning. In this respect, Franz (2009) indicated that using strategies of differentiated instruction in classrooms may provide both teachers and students with many benefits. Since differentiated instruction focuses on the strengths and needs of all students, educators are able to provide effective instruction and generate optimal results. In this regard, Scott (2012) identified the main strategies of differentiated instruction. They are compacting, independent projects, cubing, tiered assignments, whole class, interest groups, flexible grouping, learning centers, varying questions, anchoring activities, and learning contracts.

Many studies considered differentiated instruction as a powerful teaching approach for developing English reading skills and reach diverse among learners. In this respect, Kaniskan, Little, McCoach, Muller, and Reiss (2010) concluded that differentiated instruction had a great effect on improving students' reading fluency and reading comprehension. Furthermore, Gilbert (2011) revealed that the students reading achievement in the differentiated classroom was significantly higher than the students in the traditional classroom.

Besides, Bradfield (2012) indicated that differentiated instruction had a positive impact on improving reading for students who had difficulty in learning to read. Furthermore, Coar-Overall (2011) confirmed that differentiated instruction can be used to meet the needs of all diverse learners.

Based on the previous discussion, it can be inferred that reading comprehension is problematic for EFL students. Besides, differentiated instruction might be an effective approach of teaching reading and might help in developing students' reading comprehension. The present study attempted to investigate the effectiveness of differentiated instruction in developing sixth graders reading comprehension.

\section{Statement of the Problem}

The present study tried to investigate this problem: "The majority of six year primary stage students lack reading comprehension skill."

\section{Question of the Study}

The study attempted to answer this question:

"What is the effect of using differentiated instruction on developing English reading comprehension skill of sixth year EFL primary students?" 


\section{Purpose of the Study}

The present study aimed to investigate the effectiveness of using the differentiated instruction in developing English reading comprehension skill of sixth year primary students.

\section{Significance of the Study}

The study might be significant for the following reasons:

1. Findings of the study might help curriculum designers to enrich English curriculum and teachers` guide book of sixth graders with a variety of activities and practices reflecting differentiated instruction.

2. The study instrument, namely, English Reading Comprehension Test, might help other researchers and specialists in TEFL.

3. The developed questionnaires, Reading Interests (RIQ) and Learning Styles (LSQ), might broaden the EFL teachers' awareness of the students' learning preferences and so they might adapt the reading instruction and activities accordingly.

4. It might help in increasing students' achievement in reading so that their English academic achievement might be increased throughout the following school years.

5. To the best of the researcher`s knowledge, the scarcity of research addressing the use of differentiated instruction in the Egyptian EFL classroom enhances the study significance.

\section{Hypothesis of the Study}

Based on the study question, the following hypothesis was formulated:

- There is a statistically significant difference between the mean scores of the experimental (differentiated) and control (non-differentiated) groups in the posttest of English reading comprehension skill, favoring the experimental group.

\section{Delimitations of the Study}

The present study was delimited to the following:

- A group of sixth year students enrolled at Al Sadat Primary School at Qena.

- Five units of sixth graders' textbook, Time for English, first term. These units are: At the Museum, In the Restaurant, Daily Activities, Visiting a Film Studio, and In Town.

- English reading comprehension skill (A dependent variable).

- Three strategies of differentiated instruction (An independent variable) for students` grouping; interest centers, reading buddies, and tiered assignments. 


\section{Methodology and Procedures}

Sample of the Study

Participants in the present study were chosen from EFL students enrolled in the sixth grade at Al Sadat Primary School at Qena, in the academic year (2016/2017). The participants were 64 male and female students attending two classes. The subjects are Arabic native speakers learning English as a foreign language. They have studied English for five years. The average chronological age of the subjects is 11.96 years old.

\section{Design of the Study}

The present study adopted one of the most commonly used quasiexperimental designs in educational research, which is the "Pretestposttest equivalent groups". Concerning this design, William (2006) mentioned that in this design groups are selected as similar as possible; so it can fairly compare the treated group with the comparison one. But it cannot be sure the groups are comparable.

\section{Instrument of the Study}

For collecting data, English Reading Comprehension Test (ERCT) was developed and used by the researcher to carry out the experiment of the current study.

\section{English Reading Comprehension Test (ERCT)}

The ERCT was intended to measure reading comprehension skill of sixth graders. It consists of 15 items. Besides, test instructions are provided. They are written in English and translated into Arabic. General directions are given at the beginning of the test which contain information about the purpose of the test, total number of test items and time allowed to complete the test. Moreover, a pilot study was conducted to determine the validity and reliability of the study instrument. The validity of the English Reading Comprehension Test was 0.98, while the reliability was 0.96 . The collected data were statistically analyzed using SPSS (version. 16.0.).

Difficulty index of items was assessed in order to spot the test items that are too easy or too difficult. To measure the difficulty index, responses to the individual items were analyzed using the following formula given by Mitra, Nagaraja, Ponnudurai, and Judson (2009): P= $\mathrm{R} / \mathrm{T}$, where $(\mathrm{P})$ is the difficulty index, $(\mathrm{R})$ is the number of correct responses, and $(\mathrm{T})$ is the total number of responses (which includes both correct and incorrect responses). 


\section{The Effect of Differentiated Instruction on Developing English Reading Comprehension Skill of Sixth Graders}

Dr.Refat M. Bahagat Dr. Gamal M. Shehata Dr. Amer B. Ali Mr. Mahfouz H. Salem

According to Mitra et al., when the difficulty index value is less than $30 \%$, the item is too difficult, and it is considered too easy when the index value is higher than $80 \%$. On this basis, too difficult and too easy items were excluded and/or revised. Results indicated that item difficulty index of the test ranged between $33 \%-85 \%$.

Furthermore, the discrimination index of the test was determined by using this formula: $\mathrm{D}=(\mathrm{UG}-\mathrm{LG}) / \mathrm{N}$, where $(\mathrm{D})$ is the item discrimination index, (UG) is the total number of students in the upper $27 \%$ who obtained the correct response, (LG) is the total number of students in the lower $27 \%$ who obtained the correct response, and $(\mathrm{N})$ is the total number of students (Mitra, Nagaraja, Ponnudurai, \& Judson, 2009). Results showed that the item discrimination index was between $(0.23-0.69)$ which is good.

\section{Procedures of the Study}

To carry out the experiment of the study, two classes were randomly chosen. One class was assigned to serve as an experimental group (Differentiated) and the other as a control group (Nondifferentiated) by tossing a coin.

Prior to the experiment, the participants (both experimental and control groups) were given the English Reading Comprehension Test as a pre-test. Further, two feedback questionnaires were developed for grouping the study participants. First, the learning styles questionnaire which aimed to identify the preferred learning style of the participants, visual, auditory, or kinesthetic. Second, the reading interests questionnaire which purposed to recognize the participants' reading interests. Clear and simple directions regarding participants` responses to the questionnaires were provided.

Then, the experiment of the study was carried out from the middle of October 2o17 to the middle of December 2017. Time allocated for the experiment was seven weeks (three periods per week). Using differentiated instruction, the participants were taught how to decode, segment, and read aloud English words, sentences, and texts aiming to develop their reading comprehension skill. Besides, the learning environment was set up based on grouping techniques used to meet the students reading interests and learning styles. At the same time, participants in the control group were taught the same reading comprehension skills using the traditional method of teaching reading.

During implementing the experiment, differentiated worksheets including reading practices and exercises were distributed to the 
participants. In addition, there were two kinds of evaluation; summative evaluation by using the ERCT at the end of the experiment; and formative evaluation after each lesson. The teacher regularly assessed the participants` progress at the end of each lesson measuring reading comprehension skill and providing feedback. Differentiated exercises were assigned for the subjects to choose based on their reading interests, learning styles, and/or assessing preferences. After the experiment, the differentiated and non-differentiated groups were administered the English reading comprehension test as a post-test.

\section{Results of the Study}

\section{Results Concerning the Reading Comprehension Skill of both Groups in the Post-administration of the ERCT}

The independent samples t-test was used to analyze the postadministration scores. The mean scores, standard deviations, $t$-values, and $\mathrm{t}$ significance of English Reading achievement on the post-administration of the ERCT are shown in table 1.

Table 1.

T-value for English Reading Achievement of both Experimental and Control Groups in the Post-administration of the ERCT

\begin{tabular}{lccccc}
\hline Group & $\mathrm{N}$ & Mean & Std. Deviation & $\mathrm{t}$-value & Sig. level \\
\hline & & & & & \\
Experimental & 32 & 12.78 & 1.58 & 12.63 & $0.000^{*}$ \\
Control & 32 & 7.50 & 1.76 & & \\
\hline$* * \mathrm{P}<0.01$ & & & & &
\end{tabular}

Data displayed in the previous table revealed that the mean scores of the experimental and the control group in the post-administration of the ERCT regarding the reading comprehension skill were 12.78 and 7.50, respectively. It also revealed that the t-value was 12.63 . This meant that the experimental group excelled the control group in English reading comprehension skill.

In light of these results, the hypothesis of the study; "there is a statistically significant difference between the mean scores of the experimental (differentiated) and control (non-differentiated) groups in the posttest of English reading comprehension skill, favoring the experimental group", was confirmed. Further, findings were the answer for the study question of the study: What is the effect of using differentiated instruction on developing English reading comprehension 
The Effect of Differentiated Instruction on Developing English Reading

Comprehension Skill of Sixth Graders

Dr.Refat M. Bahagat Dr. Gamal M. Shehata Dr. Amer B. Ali Mr. Mahfouz H. Salem

skill of sixth year EFL primary students?"Figure 1. illustrates the findings reported in table 1 .

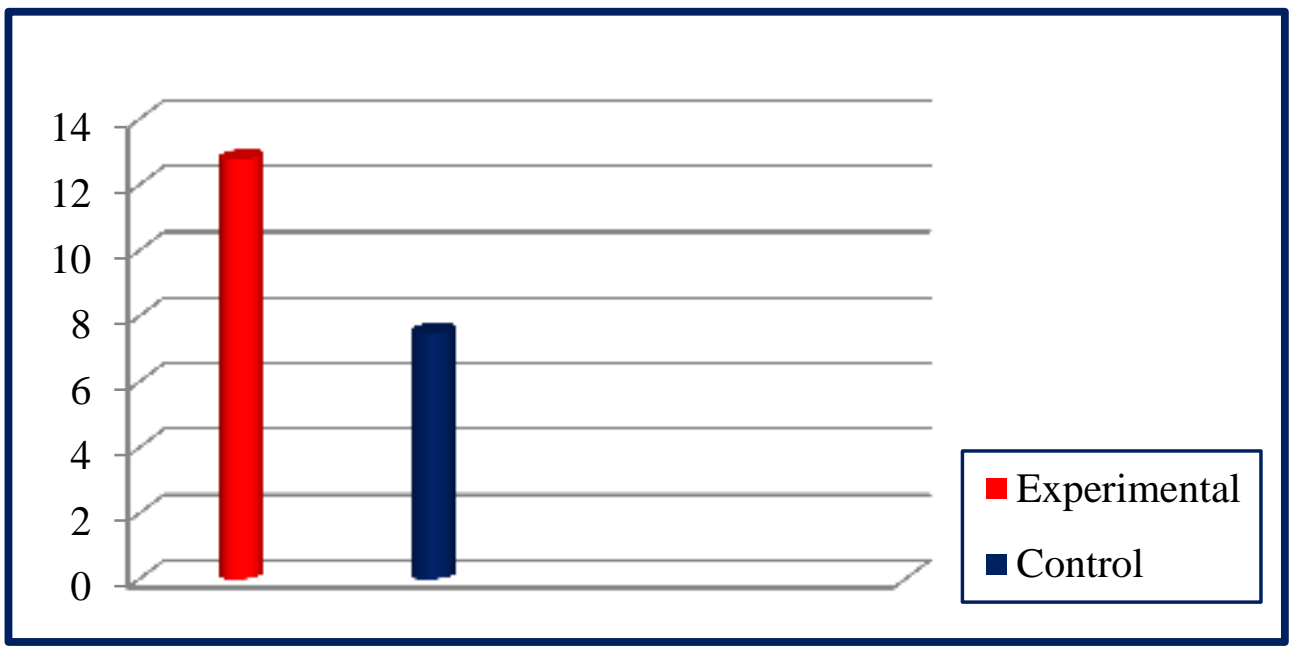

Figure 1.Comparison between Scores of both Experimental and Control Groups in the Reading Comprehension Skill (Post-administration)

\section{Results Concerning the Effect Size of Differentiated Instruction on the Reading Comprehension Skill}

For measuring the effect size "d" of using differentiated instruction (independent variable) on English reading comprehension skill (dependent variable) of the participants (experimental group), Eta Squared " $\eta^{2}$ " was computed using " $t$ " value for the differences between the means. The following was used (Howell, 1992, p. 208):

$\eta^{2}=\frac{t^{2}}{t^{2}+d f}$

Depending on " $\eta^{2}$ " value, the effect size "d" was also computed using the following statistical formula (Kiess, 1989, p. 448):

$\mathrm{d}=\frac{2 \sqrt{\eta^{2}}}{\sqrt{1-\eta^{2}}}$

According to Kiess (1989), the effect size identified whether it is large, medium, or small depending on the following:

\begin{tabular}{ccc}
\hline "d" value $=$ & 0.2 & Small \\
\hline "d" value $=$ & 0.5 & Medium \\
\hline "d" value $=$ & 0.8 & Large \\
\hline
\end{tabular}




\section{The Effect of Differentiated Instruction on Developing English Reading \\ Comprehension Skill of Sixth Graders}

Dr.Refat M. Bahagat Dr. Gamal M. Shehata Dr. Amer B. Ali Mr. Mahfouz H. Salem

Table 2. below shows the scores of t-value, " $\eta^{2}$, df (degrees of freedom), and the effect size (d) of differentiated instruction on English reading comprehension skill.

Table 2.

The Effect Size of Differentiated Instruction on English Reading Comprehension Skill Gain of the Experimental Group

\begin{tabular}{ccccccc}
$\begin{array}{c}\text { Independent } \\
\text { Variable }\end{array}$ & $\begin{array}{c}\text { Dependent } \\
\text { Variable }\end{array}$ & $\mathrm{T}$ & $\mathrm{Df}$ & $\eta^{2}$ & $\mathrm{D}$ & $\begin{array}{c}\text { Effect } \\
\text { Size }\end{array}$ \\
\hline $\begin{array}{c}\text { Differentiated } \\
\text { Instruction }\end{array}$ & $\begin{array}{c}\text { Reading } \\
\text { Comprehension }\end{array}$ & 12.63 & 32 & 0.83 & 2.1 & Large \\
\hline
\end{tabular}

Statistical results in the above table indicated that Eta square, $" \eta^{2 n}=0.83$. Further, the results revealed that the independent variable (differentiated instruction) had a large effect (2.1) on the dependent variable (English reading comprehension skill).

\section{Summary of the Results}

The results can be summarized as follows:

1. The experimental group' scores were better in the ERCT (t-value was 12.63) as compared to the control group due to differentiated instruction. Accordingly, the hypothesis of the study was confirmed.

2. Differentiated instruction had a large effect on English reading comprehension of the experimental group $(\mathrm{d}=2.1)$.

\section{Conclusions}

In light of the findings of the study, the following conclusions could be drawn:

1. Differentiated instruction is an effective approach for teaching English reading comprehension skill.

2. Differentiated instruction strategies help students learn based their reading interests and ability levels.

3. Using differentiated instruction provides learners with a comfortable and motivating learning environment that allows them to work individually, in pairs, or/and in groups based on their learning styles differences, auditory, visual, or kinesthetic learners.

4. Differentiated instruction activities and assignments provide students with opportunities to be actively involved in their learning process, hence increase their self-confidence and autonomy. 


\section{Recommendations} emerged:

Based on the study results, the following recommendations were

1. EFL instructors and curriculum designers are recommended to know more about differentiated instruction and its strategies.

2. Students` reading interests and learning styles should be taken into consideration in the implementation of differentiated instruction.

3. Much interest and care should be given to the learning environment in reading classes to make it comfortable and motivating.

4. Curriculum designers are recommended to prepare materials for primary school students that can be perceived by differentiated instruction.

\section{Suggestions for Further Research}

1. Conducting studies to use differentiated instruction with EFL students at various educational levels.

2. More research can be conducted to study the effect of differentiated instruction on developing other language skills such as listening, writing, and speaking.

3. Further research is needed to investigate students`attitudes towards differentiated instruction.

4. A study is required to investigate the effect of differentiated instruction on developing English grammar.

\section{References}

Aaron, P. G., Joshi, M., \& Williams, K. A. (1999). Not all reading disabilities are alike. Journal of Learning disabilities, 32, 120137.

Adams, M. J. (1990). Beginning to read: Thinking and learning about print. Cambridge, MA: MIT Press.

Baier, R. J. (2005). Reading comprehension and reading strategies. American Physiological Association, ( $5^{\text {th }}$ ed.).

Block, C. C., \& Pressley, M. (2002). Comprehension instruction: Research-based best practices. New York: Guilford.

Bradfield, A. (2012). The effects of differentiated instruction on struggling readers in first grade. Published Dissertation, United States: ProQuest LLC Press. 


\section{The Effect of Differentiated Instruction on Developing English Reading \\ Comprehension Skill of Sixth Graders}

Dr.Refat M. Bahagat Dr. Gamal M. Shehata Dr. Amer B. Ali Mr. Mahfouz H. Salem

Catts, H., Adlof, S., \& Weismer, S. (2006). Language deficits in poor comprehenders: A Case for the simple view of reading. Journal of Speech, Language and Hearing Research, 49, 278-294.

Coar-Overall, K. C. (2011). Effect of differentiated instruction on reading achievement. Published Dissertation, United States: ProQuest LLC Press.

D`Amico, C. (2002). The threat and challenge of illiteracy. Opening remarks at the Adolescent Literacy Workshop (International Reading Association).

Durkin, D. (1993). Teaching them to read (6 $6^{\text {th }}$ ed.). Boston, MA: Allyn \& Bacon.

Edwards, C., Carr, S., \& Siegal, W. (2006). Influences of experiences and training on effective teaching practices to meet the needs of diverse learners in schools. Journal of Education, 126, 580-592.

Elwer, A. (2014). Early predictors of reading comprehension difficulties ( $1^{\text {st }}$ ed.). Linkoping University. LiU-tryck.

Franz, C. (2009). Differentiated Instruction. La Verne, California: University of La Verne.

Gilbert, D. L. (2011). Effects of differentiated instruction on student achievement in reading. Published Dissertation, United States: ProQuest LLC Press.

Gisler, P., \& Eberts, M. (2009). Top ten ways to improve reading skills. Retrieved 25 May 2018 from:

http://school.familyeducation.com/top-10-ways/improve-reading skills/38329.html

Grabe, W. \& Stoller, F. L. (2002). Teaching and Researching Reading. Harlow: Pearson.

Gregory, G., \& Chapman, C. (2006). Differentiated instructional strategies: One size does not fit all. Thousand Oaks, CA: Corwin Press.

Hamdan, H. A. (2012). The effect of instructional scaffolding on developing some oral reading skills of EFL primary students. Egypt: Faculty of Education, SVU.

Howell, D. C. (1992). Statistical Methods for Psychology ( $3^{\text {rd }}$ ed., p. 208). Belmont CA: Duxbury Press.

Kaniskan, R., Little, C., McCoach, D., Muller, L., \& Reis, S. (2010). The effects of differentiated instruction and enrichment pedagogy on reading achievement in five elementary schools. American Educational Research Journal, 48(2), 462-501. 


\section{The Effect of Differentiated Instruction on Developing English Reading \\ Comprehension Skill of Sixth Graders}

Dr.Refat M. Bahagat Dr. Gamal M. Shehata Dr. Amer B. Ali Mr. Mahfouz H. Salem

Kent, A. (2005). Early childhood educators and literacy leaders: Powerful partners. Reading Improvement, 42(4), 238-244.

Kiess, H. (1989). Statistical concepts for the behavioral sciences. Boston: Allyn \& Bacon.

Machado, J. M. (2010). Early Childhood Experiences in Language Arts Early Literacy $\left(9^{\text {th }}\right.$ ed.). Belmont, CA: Wadsworth.

McGuire, M. (2008). Coaching to Improve Reading. Retrieved 13 January 2018 from: https://www.cecreditsonline.org/

Mitra, N., Nagaraja, H., Ponnudurai, G., \& Judson, J. (2009). The levels of difficulty and discrimination indices in type a multiple choice questions of pre-clinical semester1 multidisciplinary summative tests, IeJSME, 3(1), 2-7.

National Reading Panel (2000). Teaching children to read: Report of the National Reading Panel. Washington, D.C.: U. S. Government Printing Office.

Paris, S. G. (2005). Reinterpreting the Development of Reading Skills. Reading Research Quarterly, 40(2), 184-202.

Rock, M., Gregg, M., Ellis, E., \& Gable, R. (2008, Winter). REACH: A framework for differentiating classroom instruction. Preventing School Failure, 52(2), 31-47. Retrieved 13 August, 2017, from EBSCO host database.

Scott, B. E. (2012). The Effectiveness of Differentiated Instruction in the Elementary Mathematics Classroom. Published Dissertations, Ball State University, Muncie, Indiana.

Snow, C. E., Burns, M.S., \& Griffin, P. (Eds.). (1998). Preventing reading difficulties in young children. Washington DC: National Academy Press.

Tomlinson, C. A. (2001). Differentiated classroom: Responding to the needs of all learners. Alexandria, VA: ASCD.

Tomlinson, C. A. (2005). Quality curriculum and instruction for highly able students. Theory Into Practice, 44, 160-166.

Tomlinson, C., Brimijoin, K., \& Narvaez, L. (2008). The differentiated school: Making revolutionary changes in teaching and learning. Alexandria, VA: Association for Supervision and Curriculum Development.

William, M. K. (2006). The Nonequivalent Groups Design. Research Methods: Knowledge Base. Retrieved from: http://www.socialresearchmethods.net/kp/quasnegd.php 